\title{
Monitoring of emission of Ammonia, Hydrogen sulfide, nitrogen oxide and carbon dioxide from pig house
}

\author{
Amin Kalantarifard, Eun-Song Byeon, Yeo-Woon Ki, Go Su Yang \\ Department of Environmental Engineering, Chonbuk National University, Jeonju, South Korea
}

Email address:

Aminkalantarifard@gmail.com(A. Kalantarifard), Gsyang@jbnu.ac.kr(G. S. Yang)

\section{To cite this article:}

Amin Kalantarifard, Eun-Song Byeon, Yeo-Woon Ki, Go Su Yang. Monitoring of Emission of Ammonia, Hydrogen Sulfide, Nitrogen Oxide and Carbon Dioxide from Pig House. International Journal of Environmental Monitoring and Analysis. Vol. 1, No. 3, 2013, pp. 78-83. doi: 10.11648/j.ijema.20130103.11

\begin{abstract}
The aim of this study was to determine the concentration level of ammonia $\left(\mathrm{NH}_{3}\right)$, nitrous oxide $\left(\mathrm{N}_{2} \mathrm{O}\right)$, hydrogen sulfide $\left(\mathrm{H}_{2} \mathrm{~S}\right)$, and carbon dioxide $\left(\mathrm{CO}_{2}\right)$ in two different fattening pig houses operated with slatted floor and straw flow system. The field study was performed for three day. One large-scale pig house with capacity of 230 pigs operate with deep litter manure system under the fully slatted floor and one small-scale pig feeding operation with capacity of 200 pigs operated by scraper and straw flow system, located at the Iksan city, South Korea, were investigated in this study. Average emissions of gases on the slatted floor pig house measured were 59.8-70.5 ppm NH $\mathrm{N}_{3}, 0.048-0.78 \mathrm{ppm}_{2} \mathrm{~S}$, 453.1-650.8 ppm $\mathrm{CO}_{2}$ and 0.21-0.68 ppm $\mathrm{N}_{2} \mathrm{O}$ while the concentrations of these gases at straw flow pig house were determined as 28.17-42.53 ppm NH $3,0.11-0.43 \mathrm{ppm} \mathrm{N}_{2} \mathrm{O}, 0.018-0.043 \mathrm{ppm} \mathrm{H}_{2} \mathrm{~S}, 400.2-498.3 \mathrm{ppm} \mathrm{CO}_{2}$. In general, result of $\mathrm{H}_{2} \mathrm{~S}, \mathrm{CO}_{2}, \mathrm{~N}_{2} \mathrm{O}$ and $\mathrm{NH}_{3}$ emissions from the straw flow system were lower than values for fully slatted floor systems.
\end{abstract}

Keywords: Gas Emission, Pig House, Slatted Floor System, Straw Flow System

\section{Introduction}

Livestock activities are by far one of the largest sources of odor emission. Ammonia, hydrogen sulfide, carbon dioxide and nitrous oxide emissions coming from livestock urine and manure are considered as emissions which increase the greenhouse effects and acid rain [1]. Much of the research on gaseous emissions from pig farms has been conducted in parallel with important differences between the ways in which pigs are fed, housed and management their manure.

The gaseous odor caused by the operation of pig production facilities constitutes a serious social issue [2]. Ammonia is the most common poison in the pig's environment. The source of ammonia from poultry excreta is uric acid which under moist conditions is quickly broken down to urea and then to ammonium- $\mathrm{N}$ from which ammonia is released. Ammonia is very soluble in water and readily reacts with other substances in the atmosphere to form ammonium $\left(\mathrm{NH}_{4}{ }^{+}\right)$compounds such as ammonium sulphate which can have profound effects on natural ecosystems. Generally, ammonia levels are less than $5 \mathrm{ppm}$ in well managed pig houses. The human respiratory tract can detect levels at around $10 \mathrm{ppm}$, at levels of $50 \mathrm{ppm}$ and above the clearance of bacteria from the lungs is also impaired and therefore the animal is more prone to respiratory diseases [3]. High concentration of ammonia is generally obtained from pig-feeding operation processes compared to other odorous compounds but the contribution of this gas to odor intensity is actually insignificant because its odor threshold limit value is higher than that for other odorous compounds [4].

Sulfuric odorous compounds such as hydrogen sulfides $\left(\mathrm{H}_{2} \mathrm{~S}\right)$ are generated in lower abundance than $\mathrm{NH}_{3}$ but they contribute substantially to the total odor because their odor threshold limits are very low [5]. This gas is produced by decomposition of organic matter by anaerobic bacteria, particularly that found in faeces and slurry. The greatest source of $\mathrm{H}_{2} \mathrm{~S}$ and indeed the greatest potential for disasters comes from slurry that is held in pits beneath slatted houses. Some American states have implemented ambient hydrogen sulphide limits. For example, the Minnesota Pollution Control Agency (MPCA) has implemented a monitoring program for ambient $\mathrm{H}_{2} \mathrm{~S}$ concentrations in Minnesota, USA. At the property boundaries around livestock facilities, $\mathrm{H}_{2} \mathrm{~S}$ should not exceed $42 \mu \mathrm{g} / \mathrm{m}^{3}$ for 0.5 
$\mathrm{h}$ more than twice a week or $70 \mu \mathrm{g} / \mathrm{m}^{3}$ for $0.5 \mathrm{~h}$ more than twice a year [6].

The greenhouse gas emissions involved in livestock production are carbon dioxide $\left(\mathrm{CO}_{2}\right)$, methane $\left(\mathrm{CH}_{4}\right)$ and nitrous oxide $\left(\mathrm{N}_{2} \mathrm{O}\right)$ [7]. High concentrations of these gases can seriously affect animal health and production. As an example, $\mathrm{CO}_{2}$ or methane is considered as a cause of suffocation or asphyxiation which can displace oxygen [8].

Table 1 shows previously studies on the emissions rate of ammonia, hydrogen sulfide and carbon dioxide in pig buildings in various countries. This study was aimed at quantifying the concentration and emission levels of $\mathrm{NH}_{3}$, $\mathrm{N}_{2} \mathrm{O}, \mathrm{H}_{2} \mathrm{~S}$ and $\mathrm{CO}_{2}$ emitted from deep litter manure system under the fully slatted-floor and straw floor system from pig feeding operations, South Korea.

Table 1. Previously studies on ammonia, hydrogen sulfide and carbon dioxide production in pig buildings in various countries.

\begin{tabular}{cccc}
\hline Country & Housing type & $\begin{array}{c}\text { Conc. range } \\
\text { (ppm) }\end{array}$ & Reference \\
\hline & & $\mathrm{NH}_{3}$ & \\
England & Straw flow & $5.1-14.3$ & {$[9]$} \\
Germany & Straw flow & $12.5-27.3$ & {$[9]$} \\
& Slatted & $0.2-19.0$ & {$[10]$} \\
U.S. & Slatted & $0.3-32.1$ & {$[11]$} \\
& Slatted & $1.5-13.2$ & {$[12]$} \\
Canada & Slatted & $6.5-64.9$ & {$[13]$} \\
& Slatted & $1.9-25.9$ & {$[14]$} \\
Korea & Slatted & $6.6-12$ & {$[15]$} \\
& & $\mathrm{H}_{2} \mathrm{~S}$ & {$[16]$} \\
U.S. & Slatted & $120.0-2,174$ & {$[17]$} \\
U.S. & Slatted & $154.0-378.0$ & {$[18]$} \\
Taiwan & Slatted & $1.9-4.2$ & {$[19]$} \\
Korea & Straw flow & $17.4-20.5$ & {$[15]$} \\
& & $\mathrm{CO}_{2}$ & {$[19]$} \\
Korea & Slatted & $603-849$ & \\
Korea & Straw flow & $690-1615$ & \\
\hline
\end{tabular}

\section{Materials and Methods}

The pig houses investigated in this study were selected based on manure removal system. The types of manure removal system installed at selected houses were scraper removal system and deep litter bed manure system. The manure removal system by scraper consists of shallow manure pit with scrapers under the straw flow [20]. The floor of the pit has a smooth finish which is covered with an epoxy coating, allowing the complete removal of the manure from pig houses several times a day. The deep litter bed system is a layer of mixture manure and litter compose with sawdust or straw. The manure mixed with litter is fermented in bed and dried during the pigs growing periods and is cleaned out once a week. The deep pit manner system which has become more popular in Korea in recent years is a combination of deep manner pit under a fully or partially slatted floor [21]. Manure stored in pit for long period is removed by pooling the pit plug allowing the manure drain into a storage compartment located outside the pig house area. Pig houses arranged with straw flow scraper remove system and fully slatted floor designs are illustrated in Figure 1.

\subsection{Measurement Methods}

The concentrations of $\mathrm{H}_{2} \mathrm{~S}, \mathrm{NH}_{3}, \mathrm{CO}_{2}, \mathrm{~N}_{2} \mathrm{O}$ and two environmental parameter relatively humidity and temperate ure were measured and recorded.

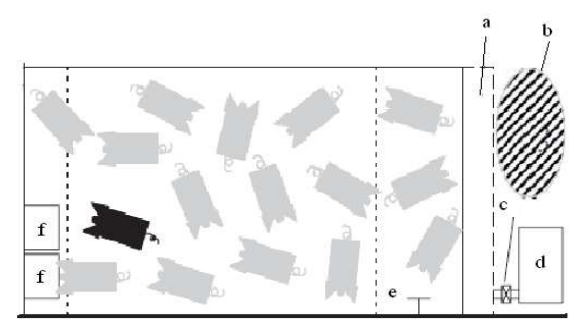

a)

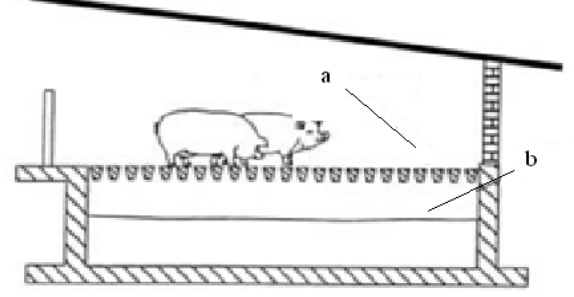

b)

Figure 1. A) House arranged with the straw flow system ( $a=$ scraped passage, $b=$ manure storage, $c=$ pump,$d=$ slurry tank, $e=$ drinker, $f=$ feeder) B) fully slatted housing system ( $a=$ concrete slats, $b=$ deep pit).

An ammonia trap system consisted of acid bottle to trap the emitted ammonia, variable area flow meter to regulate flow rate of the sweep-air and a vacuum pump to pull air through the system (Fig. 2). This method involves capturing ammonia in a boric acid solution. Experiment will be continued to determine the concentration of collected ammonia in liquid phase according to indophenols method. The sample was buffered at a $\mathrm{pH}$ of 9.5 with borate buffer in order to decrease hydrolysis of cyanates and organic nitrogen compounds and was distilled into a solution of boric acid. Alkaline phenol and hypochlorite react with ammonia to form indophenol blue that is proportional to the ammonia concentration. The blue color formed was intensified with sodium nitroprusside and measured by the OPTIZEN $1412 \mathrm{~V}$ spectrophotometer at the wavelengh of $640 \mathrm{~nm}$ [22]. In this study we used $25 \mathrm{ml}$ boric acid $(0.5 \%)$ which was placed in adsorption bottle. Air sample collected by using vacum pump with flow rate of $5.0 \mathrm{~L} / \mathrm{min}$ for $10 \mathrm{~min}$. Collected samples were transferred to laboratory for analysis.

The range of hydrogen sulfide, carbon dioxide and nitrous oxide concentration inside the pig houses were estimated by collecting the air sample in 10 liter Tedler air bag by using vacuum pump.

A schematic view of the air sample collection process is shown in Figure 3. Tedlar bag was fitted with a valve with 
unique push-pull operation and valve consistently achieves a positive open or closed setting.

The analysis of hydrogen sulfide concentration in the collected samples was carried out by SHIMADZU GC2010 gas chromatography (GC) flame photometric detector (FPD). The details of the method can be found at $[23,24]$.

$\mathrm{NO}_{2}$ analyzer model $\mathrm{KN}-210$ purchased from KNETCH company, South Korea has been used to determine the concentration of $\mathrm{NO}_{2}$ based on Chemiluminescence method (chemical reaction that produces light).

When an nitric oxide (NO) molecule reacts with ozone, it is oxidized to $\mathrm{NO}_{2}$ which in excited state. Small fraction of the molecules in this excited state with decay by emitting a photon in the near infrared portion of the spectrum. Thus, by measuring the amount of light emitted, the concentration of NOx in the mixes a gas sample with ozone may be determined.

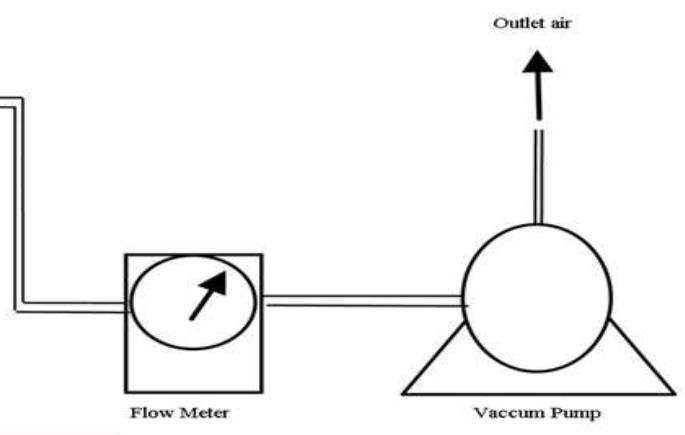

Figure 2. Schematic of ammonia absorption in boric acid.

Non Dispersed Infrared Analyzer (NDIR) method used to measure the $\mathrm{CO}_{2}$ emission in collected air sample. Each constituent of gas in a sample absorbs some infrared radiation at a particular frequency. An infrared beam is passed through a sample cell (containing $\mathrm{CO}$ or $\mathrm{CO}_{2}$ ) and the amount of infrared absorbed by the sample at the necessary wavelength is measured by a NDIR detector.

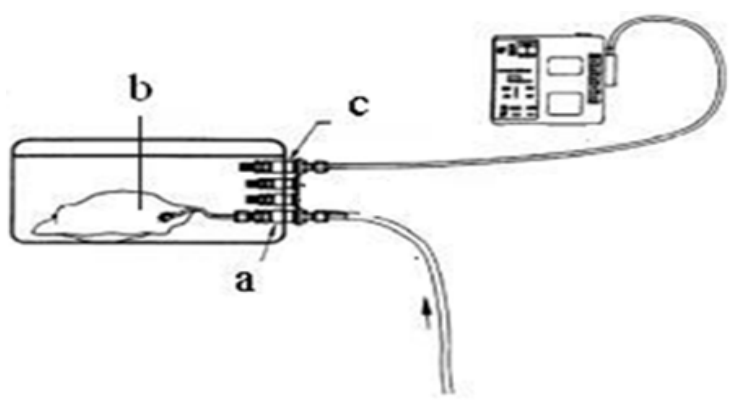

Figure 3. Schematic view of the air sample collection process. a) Sampling port, b) Tedler bag, c) vacuum port.

\section{Result and Discussion}

Range of temperature and humidity observed during the study period $\left(17^{\text {th }}\right.$ to $19^{\text {th }}$ of April, 2011) are shown in Table 2 . The mean indoor temperature in both the building was between $22.1-25.2^{\circ} \mathrm{C}$. The mean outdoor temperature ranged between $14.2-16.3^{\circ} \mathrm{C}$.

It was observed that huge amount of the heat lost occurred through the walls in both studied pig houses. Heat lost through the walls of the room with the slatted-floor system (large scale) was at a lower level compared to room with the straw flow system (small scale). The temperature range covered did not substantially influence the level of gases emission.
The characteristics of the pig farms are presented in Table 3. Pig house with slatted floor was equipped with automatic concentrate-dispensing systems where fattening pigs were kept in collective facilities. Depending upon the type of farming, two indices of stocking density have been used: live weight per unit building area and air volume available per unit. Increase in stocking density involved an increase in variability of gas emission exposure. Table 4 presents gas emission observed during the study period.

$\mathrm{NH}_{3}$ emissions were nearly two times more in a house with pigs on the slatted floor than on the straw flow. This means more $\mathrm{N}$ gaseous emission occurred with the slatted floor system. These emission may occur in form of NO, $\mathrm{N}_{2} \mathrm{O}, \mathrm{NH}_{3}$ and $\mathrm{N}_{2}$. In this study, the difference between the $\mathrm{NH}_{3}$ higher emissions of the two systems, 70.5ppm in slatted floor and $42.53 \mathrm{ppm}$ in straw flow can explain around $45 \%$ of the difference in the manure $\mathrm{N}$-content. $\mathrm{NH}_{3}$ emissions come principally from the microbial degradation of urea by enzyme urease, which is abundant in faeces [25]

In a straw flow system, the pigs excrete only in the rear of the pen which keep the lying area dry and clean. This reduces $\mathrm{NH}_{3}$ emissions since less emitting surface is used. On the other hand, it was expected that separation of liquid manure associated with storage in a hermetic tank as part of straw flow system [26] would have decreased the release of $\mathrm{NH}_{3}$. Hence, the increase in manure surface and amount of manure explains the main part of the higher estimated increase in mean daily $\mathrm{NH}_{3}$ emission from slatted floor system.

$\mathrm{N}_{2} \mathrm{O}$ emissions are mainly during gentrification, in presence of oxygen and / or low availability of degradable carbohydrates [27]. Therefore, its formation needs both 
aerobic and anaerobic conditions, these heterogeneous conditions can be found in slatted floor system.

Our result showed the released $\mathrm{N}_{2} \mathrm{O}$ emission from pig houses with slatted floor as well as straw flows are negligible. Highest level of $\mathrm{N}_{2} \mathrm{O}$ emission from slatted floor obtained were $0.68 \mathrm{ppm}$ while $0.43 \mathrm{ppm}$ measured from straw flow system. These results further confirm that $\mathrm{N}$ content emissions from the slatted-floor system are higher than emission from the straw-flow system.

The majority of the $\mathrm{CO}_{2}$ in the air of pig houses comes from animal respiration. It has to be noted that $\mathrm{CO}_{2}$ emission estimated in this study did not take into account heating energy, ventilation energy or energy involved in removing manure. The result revealed that ammonia emissions and $\mathrm{CO}_{2}$ emissions had same pattern during the study period. The $\mathrm{CO}_{2}$ emission varied with range value of
453.1-650.8 ppm in slatted floor system and 400.2-498.3 ppm in straw flow system pig house. It is reported that when the pigs are very active during the daytime, the $\mathrm{CO}_{2}$ exhalation rate is about $200 \%$ higher than at tranquil condition [28].

$\mathrm{H}_{2} \mathrm{~S}$ concentration was in range of 0.018 to $0.074 \mathrm{ppm}$ for small pig house with straw flow system while the concentration range was 0.048 to $0.78 \mathrm{ppm}$ in large scale pig house equipped by deep litter and slatted floor. $\mathrm{H}_{2} \mathrm{~S}$ formation is closely related to amount of the production of manure which depends on animal number. This is expected with the more number of pigs at large scale pig house and higher amount of manure. However, unlike $\mathrm{NH}_{3}$ the response of $\mathrm{H}_{2} \mathrm{~S}$ emission to amount of animal manure production is not immediate since more $\mathrm{H}_{2} \mathrm{~S}$ is generated from stored manure as compared to fresh manure.

Table 2. Mean temperatures and humidity observed in the experimental houses slatted floor and straw flow

\begin{tabular}{|c|c|c|c|c|c|c|}
\hline \multirow[b]{2}{*}{ Temperature $\left({ }^{\circ} \mathrm{C}\right)$} & \multicolumn{2}{|c|}{$17^{\text {th }}(10 \mathrm{am})$} & \multicolumn{2}{|c|}{$18^{\text {th }}(2 \mathrm{pm})$} & \multicolumn{2}{|c|}{$19^{\text {th }}(8 \mathrm{pm})$} \\
\hline & Mean & $\mathrm{SD}$ & Mean & SD & Mean & $\mathrm{SD}$ \\
\hline Slatted floor (L) & 23.4 & 1.3 & 25.2 & 0.42 & 25.1 & 0.38 \\
\hline Straw flow (S) & 22.1 & 0.54 & 23.5 & 1.2 & 23.9 & 1.12 \\
\hline Outside & 14.2 & 6.3 & 15.5 & 5.3 & 16.3 & 7.5 \\
\hline \multicolumn{7}{|l|}{ Humidity (\%) } \\
\hline Slatted floor & 23 & 0.7 & 21.2 & 1.03 & 20.5 & 0.6 \\
\hline Straw flow & 24.6 & 1.5 & 22.7 & 1.04 & 23.8 & 0.42 \\
\hline
\end{tabular}

$\mathrm{SD}=$ standard deviation

Table 3. Characteristics of the pig farms studied

\begin{tabular}{lccccc}
\hline $\begin{array}{l}\text { Farm } \\
\text { identification }\end{array}$ & $\begin{array}{c}\text { Management } \\
\text { system }\end{array}$ & $\begin{array}{c}\text { Type of housing } \\
\text { System }\end{array}$ & $\begin{array}{c}\text { Cleaning } \\
\text { system }\end{array}$ & $\begin{array}{c}\text { Built-up area } \\
\left(\mathbf{m}^{\mathbf{2}}\right)\end{array}$ & $\begin{array}{c}\text { Total air volume } \\
\left(\mathbf{m}^{\mathbf{3}}\right)\end{array}$ \\
\hline Large Scale & Intensive & Freestall & Slats & 350 & $1,720.00$ \\
Small Scale & Intensive & Freestall & Scraper & 230 & 92.55 \\
\hline
\end{tabular}

Table 4. Mean concentrations of $\mathrm{NH}_{3}, \mathrm{H}_{2} \mathrm{~S}, \mathrm{~N}_{2} \mathrm{O}$ and $\mathrm{CO}_{2}$ measured from two swine farms and surrounding area

\begin{tabular}{|c|c|c|c|c|c|}
\hline \multicolumn{6}{|c|}{ Mean conc. ppm } \\
\hline & Gas & Slatted floor (L) & Surrounding area & Straw flow (S) & Surrounding area \\
\hline Day $1\left(17^{\text {th }}\right)$ & $\mathrm{NH}_{3}$ & 70.5 & 2.4 & 42.53 & 1.83 \\
\hline \multirow[t]{3}{*}{ Reading time(10am) } & $\mathrm{H}_{2} \mathrm{~S}$ & 0.78 & 0.45 & 0.043 & 0.074 \\
\hline & $\mathrm{CO}_{2}$ & 650.8 & 378.6 & 498.3 & 420.5 \\
\hline & $\mathrm{N}_{2} \mathrm{O}$ & 0.68 & 0.022 & 0.43 & 0.056 \\
\hline Day $2\left(18^{\text {th }}\right)$ & $\mathrm{NH}_{3}$ & 63.09 & 1.38 & 35.86 & 1.17 \\
\hline \multirow[t]{3}{*}{ Reading time(2pm) } & $\mathrm{H}_{2} \mathrm{~S}$ & 0.055 & 0.016 & 0.028 & 0.014 \\
\hline & $\mathrm{CO}_{2}$ & 494.6 & 360.7 & 450 & 410.8 \\
\hline & $\mathrm{N}_{2} \mathrm{O}$ & 0.47 & 0.018 & 0.21 & 0.02 \\
\hline Day $3\left(19^{\text {th }}\right)$ & $\mathrm{NH}_{3}$ & 59.8 & 1.2 & 28.17 & 0.84 \\
\hline \multirow[t]{3}{*}{ Reading time $(8 \mathrm{pm})$} & $\mathrm{H}_{2} \mathrm{~S}$ & 0.048 & 0.025 & 0.018 & 0.02 \\
\hline & $\mathrm{CO}_{2}$ & 453.1 & 355.4 & 400.2 & 380.8 \\
\hline & $\mathrm{N}_{2} \mathrm{O}$ & 0.21 & 0.014 & 0.11 & 0.011 \\
\hline
\end{tabular}

Pig houses operation time start at approximately 7:30-8:00 AM The readings of gas detector were taken at 2hr (first day), 6hr (second day) and 8 hr (third day) after operation time.Surrounding area included farm perimeters.

\section{Conclusion}

Concentration level of nitrous oxide $\left(\mathrm{N}_{2} \mathrm{O}\right)$, hydrogen sulfide $\left(\mathrm{H}_{2} \mathrm{~S}\right)$, ammonia $\left(\mathrm{NH}_{3}\right)$ and carbon dioxide $\left(\mathrm{CO}_{2}\right)$ were determined in two different fattening pig houses operated by with slatted floor and straw flow system.

Concentration level of $\mathrm{NH}_{3}$ in pig house operated by slatted floor ranged from 59.8 to 70.5 while the concentration level of this gas obtained in a range of 28.17 
to 42.53 in the pig house operated by straw flow system. The results showed the higher value in both pig houses compared to previously studies.

Based on the concentration level of different gaseous in two different pig houses (Table 4), the environmental assessment of the raising of fattening pigs on the welfarefriendly straw-flow system seems to have a lower manure $\mathrm{N}$ content and lower greenhouse gas emissions in comparison with the slatted-floor system.

\section{Acknowledgments}

This work was supported financially by the climate change specialization graduate school of Chonbuk National University.

\section{References}

[1] Bolin, B., Kheshgi, H.S., 2001. On strategies for reducing greenhouse gas emissions. Proc. Natl. Acad. Sci 98, 48504854 .

[2] Ki, Y.K., Han, J.K., Hyeon, T.K., Yoon, S.K., Young, M.R., Cheol, M.L., Hyun, S.K., Chi, N.K., 2007. Sulfuric odorous compounds emitted from pig-feeding operations. Atmospheric Environment 41, 4811-4818.

[3] Walker, J.N., 1991. Fundamentals of odor cont- rol. Bio. Cycle 32, 50-55.

[4] Vranken, E., Claes, S., Hendriks, J., Darius, P., Berckmans, D., 2004. Intermittent measurements to determine ammonia emissions from livestock buildings. Biosystem Engineering 88, 351-358.

[5] O'Neill, D., Phillips, V., 1992. A review of the control of odour nuisance form livestock buildings: part 3, properties of the odorous substances which have been identified in livestock wastes or in the air-round them. Journal of Agricultural Engineering Research 53, 23-50.

[6] MPCA. Feedlot air quality summary:data collection, enforcement and program development. Minnesota Pollution Control Agency; 1999.available from www.pca.state.

[7] Nicks, B., 2004. Aspects environnementaux et zootechniques de l'e' levage de porcs charcutiers et de porcelets sevre' s sur litie 'res accumule' es de paille ou de sciure. [dissertation]. Belgium: Univ. of Lie' ge.

[8] Teye, F., Hautala, M., Pastell, M., Praks, J., Veermae, I., Poikalainen, V., Pajumägic, A., Kivinend, T., Ahokas, J., 2008. Microclimate and ventilation in Estonian and Finnish dairy buildings. Energ. Buildings 40, 1194-1201.

[9] Groot Koerkamp, P. W. G., Metz, J. H. M., Uenk, G. H. Phillips, V. R., Holden, M. R., Sneath, R. W., Short, J. L., White, R. P., Hartung, J., Seedorf, J., Schroder,M., Linkert, K. H., Pedersen,S., Takai,H., Johnsen, J. O., Wathes, C. M.,1998. Concentrations and emissions of ammonia in livestock buildings in northern Europe. Journal of agricultural engineering research70,79-95.
[10] Ki, Y., Han, J., Hyeon, T., Han, J., 2012. Comparison of seasonal concentration of ammonia and hydrogen sulfide in swine house according to pig's growth stage. Journal of Agriculture \& Life science 46,163-168.

[11] Attwood, P., Ruigewaard, R., Versloot,P. Dewit P. ,R., Heederik, D., Boleij, J.,1987. A study of the relationship between airborne contaminants and environment factors in Dutch swine confinement buildings. American Industrial Hygiene Association Journal 48, 745-751.

[12] Crook, B., Robertson, J., Glass, S., Botheroyd, E., Lacey, J., Topping, M., 1991. Airborne dust, ammonia, microorganisms, and antigens in pig confinement houses and the respiratory health of exposed farm workers. American Industrial Hygiene Association Journal 52, $271-$ 279.

[13] Morrison, D., Pirie, D., Perkins, S., Braithwaite, A., Smith, J., Waterfall, D., Douce-tt, C., 1993. Gases and respirable dust in confinement buildings and the response of animals to such airborne contaminants. ASAE. 735-746.

[14] Duchaine, C., Grimard, Y., Cormier, Y., 2000. Influence of building maintenance, environmental factors, and seasons on airborne contaminants of swine confinement buildings. American Industrial Hygiene Association Journal 61, 56 63.

[15] Lee, S, H., Choi, K, J., Oh, K, Y., Yu, B, K, Lee, I, B., Kim, $\mathrm{K}, \mathrm{W}$., 2005. Measurement of ammonia emission rate and environmental parameters from growing-finishing and farrowing house during hot season. Journal of lives Hous \& Env 11,1-10.

[16] Avery, G.L., Merva, G.E., Gerrish, J.B., 1975. Hydrogen sulfide production in swine confinement units. Transactions of the ASAE 18, 149-151.

[17] Ni, J.Q., Heber, A.J., Diehl, C.A., Lim, T.T., Duggirala, R.K., Haymore, B.L., 2002. Characteristics of hydrogen sulfide concentrations in mechanically ventilated swine buildings. Canadian Biosystems Engineering 44, 611-619.

[18] Chang, W., Chung, H., Huang, F., 2001. Exposure assessment to airborne endotoxin, dust, ammonia, hydrogen sulfide and carbon dioxide in open style swine houses. Annals of Occupational Hygiene 45, 457-465.

[19] Won, G,Y., Cho, L, K., Myung, G, L., Dong, K, K., 2012. Analysis of changing pattern of Noxious gas levels with malodorous substance concentration in individual stage of pig pens for $24 \mathrm{hrs}$ to improve piggery environment. Journal of lives Hous \& Env 18.25-34.

[20] Chénard, L ., Lemay, S., Laguë, C., 2003. Hydrogen sulfide assessment in shallow-pit swine housing and outside manure storage. J Agric Saf. Health 9, 285-302.

[21] Ki, Y., Han, J., Hyeon, T., Chi, N., Yoon, S., 2008. Assessment of airborne bacteria and fungi in pig buildings in Korea. Bio systems engineering 99, 565-572.

[22] Kawashima, S., Yonemura, S., 2001. Measuring ammonia concentration over a grassland near livestock facilities using a semiconductor ammonia sensor. Atmo Envir 35, 38313839 .

[23] Kevin, B., Thurbide, A., Brad, W., Cooke, A., Walter, A., 2004. Novel flame photometric detector for gas 
chromatography based on counter current gas flows. Journal of Chromatography 1029, 193-203.

[24] Eiceman, H,. 1998. Flame photometric detector for gas chromatography based on counter-current gas flows. J. Gardea Torresdey Anal Chem. 70, 321-326.

[25] Muck, R., Steenhuis, S., 1981. Nitrogen losses in free stall dairy barns. In Livestock waste. American Society of Agricultural Engineering.406-409.Mn.us/index.php /viewdocument.html

[26] Groenestein, C., Den, H., Metz, J., 2006. Potential ammonia emissions from straw bedding, slurry pit and concrete floors in a grouphousing system for sows. Biosystems Engineering 95, 235-243.

[27] Poth, M., Focht, D., 1985. 15N kinetic analysis of N2O production by Nitrosomonas europaea: an examination of nitrifier denitrification. Applied and Environmental Microbiology 49, 1134-1141.

[28] Ni, J., Hendriks, J., Coenegrachts, J., Vinckier, C., 1999. Production of carbon dioxide in a fattening pig house under field condition. Atmospheric Environment 33, 3691- 3696. 